\title{
An Introduction to the Journal of Scientific Practice and Integrity
}

\author{
Tess Bird, DPhil and David S. Egilman, MD, MPH
}

\section{Why a journal of Scientific Integrity and Practice?}

Corruption in science is a significant problem in the United States and abroad, especially in fields that impact potential economic growth. While many reputable journals have published on scientific integrity, we recognize a need to provide ongoing critical attention to the diverse means used to manipulate science and science policy. This journal is an independent, peer-reviewed, open-access publication, as well as a call for greater integrity in scientific practice.

\section{Scientific Integrity: A History and Current Debates}

Contemporary research ethics and practice in the United States were influenced by a series of significant historical events that raised concerns about the value of scientific progress versus the value of human life. The Tuskegee Syphilis Study (1932-1972), experimentation by Nazi scientists on concentration camp prisoners (1939-45), and ongoing experiments on prisoners, the mentally or terminally ill, Native Americans and other minority groups in the U.S. are perhaps some of the more infamous humanrights abuses in the name of science. ${ }^{1-4}$ Further back, in the nineteenth century, a growing awareness of the toxic effects of industry on workers was the subject of much public debate in the US and Europe, leading to increased industrial regulation. In addition to human health, the health of the environment has also been called into question. Perhaps most famously, Rachel Carson's 1961 book, Silent Spring, brought attention to the effects of toxins on the environment, resulting in the campaign to ban the use of DDT in the US. While these examples led to considerable positive changes in infrastructure and regulation, and have helped strengthen ecological, consumer, and worker health over time, scientific misconduct and political-economic practices that impact human and environmental health are far from resolved.

Globally, research still remains fraught with ethical concerns, including experimentation on vulnerable populations and the foisting of dangerous working conditions on other countries as nations "modernize." Investigating and regulating environmental toxins on a global scale is also an increasingly urgent necessity. There are countless accounts of the manipulation of science and publishing to show results that are favorable to industry, often at the expense of human and environmental health. ${ }^{8}$ Considerable attention has been paid to tobacco, ${ }^{9,10}$ asbestos, ${ }^{11-13}$ oil, Big Pharma, medical device companies, and the food and beverage industry. ${ }^{9,10,14-20}$

Policy changes in the last decades of the $20^{\text {th }}$ century have created a new climate for scientific research, particularly in the U.S., by increasing the number of industry-academic partnerships. ${ }^{21}$ The often cited U.S. Bayh-Dole Act of 1980 allowed university researchers, small businesses, and nonprofit institutions to obtain private patents on federally funded research. ${ }^{21-25}$ The Stevenson-Wydler Technology Innovation Act of 1980 similarly encouraged cooperation between industry, government, and universities. ${ }^{21,26}$ These and other changes to US law led to a flourishing of commercial-academic partnerships that did not go uncontested. .2, 23,25 Politicians and scientists alike questioned the unintended consequences of such policy changes on academic research, including conflicts of interest, allocation of resources, and the use of gifts to influence behavior. ${ }^{21}$ However, many of these changes are now embedded in the way that we view scientific practice. As Sheldon Krimsky describes in his book Science in the Private Interest, "the successful scientist today is the person who can make contributions to the advancement of knowledge while concomitantly participating in the conversion of new knowledge to marketable products." 21 Legal scholar and bioethicist Trudo Lemmons similarly explains that since the 1970s there has been an ideological shift from recognizing science as a public good to considering it a private enterprise. ${ }^{23}$

Retrospectively, it is clear that while such legal and policy changes spurred significant biotechnical advancements and opened new markets, the resultant climate has cultivated possibilities for the type of corruption that is inherent in partnerships driven by sales and profit. ${ }^{23,25}$ For instance, in their systematic review of biomedical research publications, Bekelmen et al. found a "statistically significant association between industry sponsorship and pro-industry conclusions." 22

Researchers in multiple countries have labeled a variety of other concerns in scientific research, including: financial and other conflicts of interest; ${ }^{22,27,28}$ selective reporting and 
publication bias, or the publication of favorable and positive results over negative ones, particularly regarding industryfunded studies; ${ }^{29,30}$ publication ethics in medical journals; ${ }^{31-}$ 33 ghost-writing of industry-funded publications ${ }^{19,34-36}$ or "ghost-management" of information delivery; ${ }^{37}$ the influence of industry on academic careers (e.g. attacks on whistleblowers); $;^{38,39}$ the influence of pharmaceutical sales representatives and financial perks on physician or student perspectives; ${ }^{40,41}$ manipulation of data, such $\mathrm{p}$-hacking to find statistically significant results or ending studies early for benefit; $30,38,42,43$ the convergence of marketing and research (e.g. seeding trials); ${ }^{44,45}$ perverse incentives in academia; ${ }^{38}$ industry influence on the integrity of standard scientific practices, such as epidemiology or meta-analyses; $9,39,46,47$ the influence of socio-political contexts; ${ }^{47-49}$ and the role of regulatory bodies. ${ }^{37,50,51}$ This list goes on, and these citations are not exhaustive.

In response to growing ethical questions surrounding scientific integrity in a profit-driven economy, there have been calls for more transparency as well as several initiatives to account for industry-influenced biases in the scientific canon. ${ }^{22,32}$ The BMJ, for instance, publishes papers from the Restoring Invisible and Abandoned Trials initiative, "through which academics who find previously unreported trials can write them up and publish them if the original investigators decline to do so." 32 Others have published tips and methods for recognizing misconduct. ${ }^{52-54}$

The influence of industry on research is of course not limited to the biomedical sciences. Attention has also been paid to the effects of industry-sponsored research on the environment as well as consumer safety. ${ }^{55}$ JoSPI seeks articles that address all aspects of human and environmental health (and even wellbeing) in relation to concerns about scientific practice and integrity. Further, while this review concentrates on the U.S., where JoSPI is based, we encourage insights from international scholars.

\section{The Insidious Nature of Scientific Misconduct}

Scientific misconduct, while a broad category, is notably intentional, often including deceit, neglect, fabrication, falsification, or plagiarism. ${ }^{55}$ Scholars have recognized that this intentionality or deliberate nature of scientific misconduct differentiates it from simply poor science or honest error. ${ }^{55}$ However, we note that the seeping of misconduct into scientific practice can be a slow and devious one, where participants are not always fully conscious of their roles. At the smallest scale, this includes the "mundane 'regular' misbehaviors" 42 that might lead to a certain leniency around more extreme types of misconduct down the line. In their review of such behaviors, Martinson and colleagues provide several examples, including publishing the same data or results in two or more publications, inadequate or inappropriate research designs, and dropping observations or data points based on "a gut feeling." 42

We agree that there is need for recognizing the role that broader research environments play in cultivating misconduct. ${ }^{23,38,42}$ Science and medicine take place in social settings where misconduct can become normalized in the group culture of an organization. ${ }^{48,49}$ This includes the "perverse incentives" of an academic climate that focuses on production and funding. ${ }^{38}$ At JoSPI we are interested in investigating these nuances, recognizing the susceptibility of even "ethical" individuals to hegemonic systems of thought.

Indeed, we acknowledge that the ways in which industry influences scientific practice can be subtle and difficult to identify, hitting methodological roadblocks. Often times, identifying misconduct involves reviewing corporate documents uncovered during lawsuits or through laws allowing public access to government documents. Access to litigation documents is often limited to lawyers and experts privy to the details of a legal case, where these documents are sometimes designated confidential and thus remain hidden from public scrutiny. Once (and if) these documents are de-designated, experts are able to publish on their findings. While we note that there are conflicts of interest in such research, such as being a paid consultant to litigation, publication is one of the few methods available to draw attention to these valuable source materials within the scientific community. This is why part of our practice at the JoSPI will be to put otherwise unavailable public documents on the web for others to review. We are also interested in highlighting other methodological roadblocks for studying scientific practice.

\section{An Interdisciplinary Approach}

In recent years, some scholars have raised concerns about "science" losing the public's trust. Edwards and Roy warn: "If a critical mass of scientists become untrustworthy, a tipping point is possible in which the scientific enterprise itself becomes inherently corrupt and public trust is lost, risking a new dark age with devastating consequences to humanity." 48 To further this point, with the current political assault on science, scientists and researchers must be even more conscientious of the effects of corruption on the public's trust. We also recognize that due to the insidious nature of commercial-scientific partnerships, maintaining scientific integrity now more than ever calls for an interdisciplinary research approach that challenges the assumptions of a scientific thinking embedded in a history of capitalist progress. There is a large and growing body of work that critically examines science from social, cultural, and historical perspectives, shedding light on such 
embedded assumptions. Social Scientist Bruno Latour has long noted that truth only exists in relation to the social and material structures that maintain it. ${ }^{56}$ In other words, it's our infrastructure, networks, and practice that make science real; without them, facts falter. For this reason, we not only gladly review articles from social scientists, but we also encourage the submission of work that tackles problems in the infrastructures that keep scientific integrity in places, such as universities, governmental organizations, and the workplace.

\section{We also identify several new areas for inquiry}

Legal and regulatory testimony has a huge impact on health policy but is never peer reviewed. Scientists may be much more careful about the contents of their testimony if they thought it might be peer reviewed in a published commentary. At JoSPI, we want to provide a forum for that process through our "Reviews of Legal Testimony" section.

We are also interested in undergraduate student research and commentaries that reflect on the rising generation. For this reason, we have introduced a "Student Essay" section, which will be peer-reviewed by other undergraduate students.

We also encourage submissions from a global community of scholars and offer English language editing services upon request.

\section{The Past and the Future}

As a final note, addressing corruption in scientific practice takes critical reflection on both the past, including historical research, and the future. We thus encourage articles that address the ongoing concerns of scientific integrity, including commentaries regarding potential or probable

\section{References}

1. CDC. How Tuskegee Changed Research Practices. https://www.cdc.gov/tuskegee/after.htm. Published 2015. Accessed March 27, 2019.

2. The Nuremberg Code. In: Trials of War Criminals before the Nuremberg Military Tribunals under Control Council Law No. 10, Vol. 2. Washington D.C.: U.S. Government Printing Office; 1947:181-182. https://history.nih.gov/research/downloads/nuremberg.pdf \%OA. Accessed January 20, 2019.

3. Hornblum AM. Acres of Skin: Human Experiments at Holmesburg Prison. London: Routledge; 1998.

4. Loue S. Textbook of Research Ethics: Theory and Practice. Springer Science \& Business Media; 2007.

5. Petryna A. Ethical variability: Drug development and futures.

It is our hope that JoSPI will grow into a rigorous, interdisciplinary community that provides a forum for debate and discussion and generate inquiry into scientific practice and integrity for many years to come.

David Egilman, MD, MPH, is board-certified in internal medicine and preventive and occupational medicine, and an epidemiologist. He is the former Editor in Chief of the International Journal of Occupational and Environmental Health. His research interests are broad, including the corporate corruption of science, the marketing of toxic pharmaceuticals, silicone implants, radiation exposure, asbestos exposure, and health in under-developing countries. He also researches the history of the development of knowledge of warnings and health effects and the epistemology of scientific knowledge. He has served as an expert witness in toxic tort litigation. This work has uncovered many different types of corporate and government malfeasance. Dr. Egilman is currently Clinical Professor of Family Medicine at Brown University. He is the Editor-in-Chief of JoSPI.

Tess Bird, DPhil, MSc., is a medical anthropologist and interdisciplinary social science researcher. Her research considers the human negotiation of uncertainty, from individual tactics for managing uncertainty, to resilience and sustainability during environmental change, and to misconduct in scientific practice. She has conducted research on asbestos, pharmaceuticals, medical devices, and global health at Never Again Consulting. Dr. Bird is currently a Mellon Postdoctoral Fellow in Writing for the Social Sciences at Wesleyan University. She is also affiliated with the Institute of Social and Cultural Anthropology at Oxford University and the Oxford Unit for Biocultural Variation and Obesity. She is Managing Editor of JoSPI. globalizing clinical trials. Am Ethnol. 2005;32(2):183-197.

6. Petryna A. Clinical Trials Offshored: On Private Sector Science and Public Health. Biosocieties. 2007;2(1):21-40. doi:10.1017/S1745855207005030

7. Roman J. U.S. Medical Research in the Developing World: Ignoring Nuremberg. Cornell J Law Public Policy. 2002;11(2). http://scholarship.law.cornell.edu/cjlpp\%0Ahttp://scholarshi p.law.cornell.edu/cjlpp/vol11/iss2/4.

8. Walker MJ. A Dark Culture - The History and Literature of Health-Damaging Production, its Exposure, and its Corporate Defense. In: Walker MJ, ed. Corporate Ties That Bind: An Examination of Corporate Manipulation and Vested Interest in Public Health. New York: Skyhorse Publishing; 2017.

9. Ong EK, Glantz SA. Constructing "sound science" and "good epidemiology": Tobacco, lawyers, and public relations firms. 
Am J Public Health. 2001;91(11):1749-1757.

doi:10.2105/AJPH.91.11.1749

10. Oreskes N, Conway EM. Merchants of Doubt: How a Handful of Scientists Obscured the Truth on Issues from Tobacco Smoke to Global Warming. New York: Bloomsbury Press; 2010.

11. Egilman DS, Bird T, Lee C. MetLife and its corporate allies: Dust diseases and the manipulation of science. Int J Occup Environ Health. 2013;19(4). doi:10.1179/2049396713Y.0000000033

12. Egilman $D$, Bird $T$, Lee $C$. Dust diseases and the legacy of corporate manipulation of science and law. Int J Occup Environ Health. 2014;20(2):115-125. doi:10.1179/1077352514Z.000000000104

13. Egilman DS, Bohme SR. Over a Barrel: Corporate Corruption of Science and Its Effects on Workers and the Environment. Int J Occup Env Heal. 2005;11:331-337.

14. Moodie R, Stuckler D, Monteiro C, et al. Profits and pandemics: prevention of harmful effects of tobacco, alcohol, and ultra-processed food and drink industries. Lancet. 2013;381(9867):670-679. doi:10.1016/S01406736(12)62089-3

15. Michaels D. Doubt Is In Their Product: How Industry's Assult on Science Threatens Your Health. New York, NY: Oxford University Press; 2008.

16. Michaels D, Monforton C. Manufacturing Uncertainty: Contested Science and the Protection of the Public's Health and Environment. Am J Public Health. 2005;95(S1):S39-S48. doi:10.2105/AJPH.2004.043059

17. Stuckler D, McKee M, Ebrahim S, Basu S. Manufacturing epidemics: the role of global producers in increased consumption of unhealthy commodities including processed foods, alcohol, and tobacco. PLoS Med. 2012;9(6):1-8. doi:10.1371/journal.pmed.1001235

18. Shulman S, Abend K, Meyer A, et al. Smoke, Mirrors, and Hot Air: How ExxonMobil Uses Big Tobacco's Tactics to Manufacture Uncertainty on Climate Science. Cambridge, MA: Union of Concerned Scientists; 2007.

19. Krumholz $\mathrm{H}$, Vioxx R. What Have We Learnt from Vioxx? $\mathrm{Br}$ Med J. 2014;334(7585):120-123.

20. Steffen J, Fassler E, Reardon K, Egilman D. Grave fraudulence in medical device research: a narrative review of the PIN seeding study for the Pinnacle hip system. Account Res. 2018;25(1):37-66. doi:10.1080/08989621.2017.1405259

21. Krimsky S. Science in the Private Interest: Has the Lure of Profits Corrupted Biomedical Research. Oxford: Roman and Littlefield Publishers, Inc.; 2003.

22. Bekelman JE, Gross CP. Scope and Impact of Financial Conflicts of Interest in Biomedical Research. J Am Med Assoc. 2014;289(4).

23. Lemmens T. Leopards in the Temple: Restoring Scientific Integrity to the Commercialized Research Scene. In: International and Comparative Health Law and Ethics: A 25Year Retrospective. ; 2004:641-657.
24. Gelberman RH, Samson D, Mirza SK, Callaghan JJ, Pellegrini VD. Orthopaedic Surgeons and the Medical Device Industry. J Bone Jt Surgery-American Vol. 2010;92(3):765-777. doi:10.2106/JBJS.I.01164

25. Rowe S, Alexander N, Clydesdale FM, et al. Funding food science and nutrition research: financial conflicts and scientific integrity. Am J Clin Nutr. 2009;89(C):1285-1291. doi:10.3945/ajcn.2009.27604.Am

26. Stevenson Wydler Technology Innovation Act of 1980. 96th Congress https://www.congress.gov/bill/96thcongress/senate-bill/1250.

27. Lexchin J, Bero LA, Djulbegovic B, Clark O. Pharmaceutical Industry Sponsorship And Research Outcome And Quality: Systematic Review. BMJ Br Med Journal,. 2003;326(7400):1167-1170.

28. Warner TD, Roberts LW. Scientific integrity, fidelity and conflicts of interest in research. Curr Opin Psychiatry. 2004;17(5):381-385. doi:10.1097/01.yco.0000139974.45189.96

29. Melander H, Ahlqvist-Rastad J, Meijer G, Beermann B. Evidence B(I)Ased Medicine: Selective Reporting From Studies Sponsored By Pharmaceutical Industry: Review Of Studies In New Drug Applications. Br Med J. 2003;326(7400):1171-1173.

30. Montori VM, Devereaux PJ, Adhikari NKJ, et al. Randomized Trials Stopped Early for Benefit. Am Med Assoc. 2005;294(17):2203-2209. doi:10.1001/jama.294.17.2203

31. Smith R. The trouble with medical journals. J R Soc Med. 2006;99(3):115-119. doi:10.1258/rsmmlj.76.3.79

32. Smith R, Gøtzsche PC, Groves T. Should journals stop publishing research funded by the drug industry? BMJ. 2014;348(January). doi:10.1136/bmj.g171

33. Smith R. Medical journals are an extension of the marketing arm of pharmaceutical companies. PLoS Med. 2005;2(5):0364-0366. doi:10.1371/journal.pmed.0020138

34. Flanagin A, Carey LA, Fontanarosa PB, et al. Honorary Authors and Ghost Authors in Peer-Reviewed Medical Journal. J Am Med Assoc. 1998;280(3):222-224. http://www.amaassn.org/public/peer/7_15_98/jpv80004.htm.

35. Healy D, Cattell D. Interface between authorship, industry and science in the domain of therapeutics. Br J Psychiatry. 2003;183(July):22-27. doi:10.1192/bjp.183.1.22

36. Drummond R, Flanagin A. Authorship! Authorship! JAMA. 1994;271(6):469-471.

37. Cosgrove L, Vannoy S, Mintzes B, Shaughnessy AF. Under the Influence: The Interplay among Industry, Publishing, and Drug Regulation. Account Res. 2016;23(5):257-279. doi:10.1080/08989621.2016.1153971

38. Edwards MA, Roy S. Academic Research in the 21st Century: Maintaining Scientific Integrity in a Climate of Perverse Incentives and Hypercompetition. Environ Eng Sci. 2017;34(1):51-61. doi:10.1089/ees.2016.0223

39. Tong $\mathrm{S}$, Olsen J. The threat to scientific integrity in 
environmental and occupational medicine. Occup Environ Med. 2005;62(12):843-846. doi:10.1136/oem.2005.021410

40. Austad KE, Avorn J, Kesselheim AS. Medical Students' Exposure to and Attitudes about the Pharmaceutical Industry: A Systematic Review. PLoS Med. 2011;8(5):1-12.

41. Sah S, Fugh-Berman A. Physicians under the Influence: Social Psychology and Industry Marketing Strategies. J Law, Med Ethics. 2013.

42. Martinson BC, Anderson MS, De Vries R. Scientists behaving badly. Nature. 2005;435(7043):737-738. doi:10.1038/435737a

43. Fanelli D. How Many Scientists Fabricate and Falsify Research? A Systematic Review and Meta-Analysis of Survey Data. PLoS One. 2009;4(5):e5738. https://doi.org/10.1371/journal.pone.0005738.

44. Hill KP, Ross JS, Egilman DS, Krumholz HM. Annals of Internal Medicine Article The ADVANTAGE Seeding Trial: A Review of Internal Documents. Ann Intern Med. 2008;149:251-258.

45. Sox HC, Rennie D. Annals of Internal Medicine Editorial Seeding Trials: Just Say “No." Ann Intern Med. 2008;149:279280.

46. Noble JH. Meta-analysis: Methods, strengths, weaknesses, and political uses. J Lab Clin Med. 2006;147(1):7-20. doi:10.1016/j.lab.2005.08.006

47. Tweedale G. The Rochdale Asbestos Cancer Studies and the Politics of Epidemiology: Rochdale Asbestos Cancer Stud Polit Epidemiol What You See Depends Where You Sit. 2007;13(1):70-79.

48. Hedgecoe A. A deviation from standard design? Clinical trials, research ethics committees, and the regulatory coconstruction of organizational deviance. Soc Stud Sci.
2014;44(1):59-81.

49. Mumford MD, Helton WB. Organizational influences on scientific integrity. Investig Res Integr Proc first ORI Res Conf Res Integr. 2001;5583(1):73-90.

50. McCabe AR. A Precarious Balancing Act - The Role of the FDA as Protector of Public Health and Industy Wealth. Suffolk Univ Law Rev. 2003;787(1):787-197. doi:10.3868/s050-004015-0003-8

51. Lynch MJ, Burns RG, Holcomb JE. Food for thought: An investigation of food and drug administration reporting practices, 1995-1999. Crim Justice Rev. 2005;30(3):293-311. doi:10.1177/0734016805285177

52. Gupta A. Fraud and misconduct in clinical research: A concern. Perspect Clin Res. 2013;4(2):144-147. doi:10.4103/2229-3485.111800

53. Mitchell M, Murray M, Salomon J, et al. Users' guide to detecting misleading claims in clinical research reports. BMJ Br Med J. 2004;329(November):1093-1096.

54. Gunsalus CK, Robinson AD. Nine pitfalls of research misconduct. Nature. 2018;557(7705):297-299. doi:10.1038/d41586-018-05145-6

55. Merlo DF, Vahakangas K, Knudsen LE. Scientific integrity: Critical issues in environmental health research. Environ Heal A Glob Access Sci Source. 2008;7(SUPPL. 1):1-8. doi:10.1186/1476-069X-7-S1-S9

56. Kafman A. Bruno Latour, the Post-Truth Philosopher, Mounts a Defense of Science. The New York Times. https://www.nytimes.com/2018/10/25/magazine/brunolatour-post-truth-philosopher-science.html. Published October 25, 2018. 